\title{
An exploratory study of 'close' supplier-manufacturer relationships
}

\author{
Keith Goffin, Fred Lemke and Marek Szwejczewski \\ Cranfield School of Management, Cranfield MK43 0AL, England
}

Address for correspondence (note this is a change from original submission):

Professor Keith Goffin

Cranfield School of Management

Cranfield, Bedford MK43 0AL

England, UK

Tel.: +44 (0) 1234-754871

Fax: +44 (0) 1234-751806

Email: k.goffin@cranfield.ac.uk

\begin{abstract}
Close relationships with selected suppliers can enable manufacturers to reduce costs, improve quality and enhance new product development. Although the advantages of close cooperation are widely acknowledged in the literature, the specific attributes of such relationships are not well understood. To address this gap, 39 managers responsible for purchasing were interviewed using a technique from psychology, which is particularly effective at uncovering the characteristics of relationships. This approach is innovative in the context of supplier management research and gave insights into how manufacturers expect more of their suppliers than just reliable deliveries of high-quality, well-priced parts and components. The results of the empirical research enhance our knowledge of the attributes of manufacturer-supplier relationships and also indicate how manufacturers can establish close relationships with selected suppliers. Overall, the study has established the viability of a new approach for understanding the complex topic of manufacturer-supplier partnerships.
\end{abstract}


Keywords: Purchasing, supply management.

\section{Introduction}

The value of effective supplier management is well known. Applied appropriately, it can significantly improve a manufacturer's performance in terms of cost reduction, achieving constant improvements in quality levels, and enhancing new product design (Monczka et al., 1993; Primo and Amundson, 2002). To achieve these advantages, practitioners have recognized the necessity of working closely with their suppliers, in what are often termed "partnerships" (e.g. Fretty, 2001; Kerns, 2000). Many academic studies have pointed to the advantages to be gained from cooperation with suppliers (e.g., Carr and Pearson, 1999; Monczka et al., 1993). Surprisingly, however, our understanding of the nature of supplier-manufacturer relationships remains limited.

Until the 1990s, manufacturers focused primarily on cost, quality and delivery in their dealings with suppliers and relationships were often "transactional" and "adversarial". Manufacturers then started to consider a much wider range of factors; including a supplier's competencies, the overall service provided, financial stability and even the supplier's organizational culture (Goffin, 1997; O'Toole and Donaldson, 2002). As it became recognized that suppliers could make longer-term contributions, for example to product innovation, a stream of literature started to recommend the development of partnerships with suppliers. For example Metcalf et al. (1992, p27) stated that "the more cautious, arm's-length relationships of the past are giving way to closer buyer-seller co-operation, driven by the perception that there are greater benefits to be obtained through such partnerships." In recent years managers have widely 
adopted the term partnership but they appear to use it in referring to a range of different relationships (McCutcheon and Stuart, 2000). In fact, partnership has become a "buzzword" because, as Brennan (1997, p768) notes, "fashionable managerial expressions are prone to overuse, abuse and consequently to devaluation... the same fate awaits, or may already have befallen 'buyer/supplier partnership'.”

Although relationships are often discussed in the extant literature, there is a gap: how do managers perceive the range of different relationships they have with organizations in their supplier base? Our understanding of supplier-manufacturer relationships has been clouded by the implicit assumption that partnerships are always desirable and by the limitations of trying to understand the nature of complex relationships using direct questioning alone. The variety of conditions that lead to, affect or characterize close relationships is not adequately understood. In consequence, this paper describes how managers perceive relationships with their suppliers. The goal of the research was a better understanding of relationships, in order that they can be better managed. The current study is part of a wider program of research on supplier management, which focused on Germany because of the importance and reputation of its manufacturing sector (Rommel, 1991). The overall study took a multiple methods approach and the research described in this paper was based on 39 in-depth interviews. These utilized a technique from psychology for investigating inter-personal relationships-repertory grid technique. The application of this technique to supplier management research is new. The results are important as they give a clearer understanding of relationships, demonstrate the viability of the methodology, and have implications for practitioners-indicating how they can manage their suppliers more effectively.

This paper has five further sections. Section 2 reviews the literature on manufacturersupplier relationships. Section 3 presents the research question and explains the methodology. 
The results are covered in Section 4, followed by a comprehensive discussion of the findings and implications for both researchers and practitioners (Section 5). Finally, Section 6 presents the overall conclusions and ideas for further research.

\section{Supplier-manufacturer relationships}

Relationships between manufacturers and their suppliers are typically called "suppliermanufacturer relationships". The term "buyer-supplier relationships" is broader in that it can also be used to refer to relationships between companies in the service sector. As this paper focuses on manufacturing, we will use the former term but shorten it to "supplier relationships" throughout. Supplier relationships range from transactional to close ones. In conducting research on relationships, it is important to recognize that the way in which the term "partnership" has been commonly used has led to confusion for three main reasons:

a) Relationships between manufacturers and suppliers are a form of business relationship, which are often described as partnerships. This does not infer that they have the same legal basis as a formal business partnership, or alliance. We propose that a better term would be "partnership-like" relationships, indicating a relationship that is not based on legal definitions;

b) Partnership-like relationships are context dependent rather than being an absolute concept. Several researchers have recognized that partnership-like relationships vary depending on how "close" they are (e.g. Ellram, 1991; Saxton, 1997). Therefore, the degree of closeness offers a way to both explore and explain relationships, including partnership-like relationships; 
c) Partnership-like relationships are not appropriate for the whole of the supplier base (although, as we will see, this is almost universally assumed).

As indicated in the introduction, there is a wide literature on the value of close supplier relationships but we will exclude this from our review as we are focusing on the nature of relationships themselves. Three topics are pertinent to the current study and important to help in clarifying the concepts involved:

- The appropriateness of close relationships;

- Building and maintaining close relationships;

- The nature of close relationships.

\subsection{The appropriateness of close relationships}

Much of the literature has implied that close relationships with suppliers are always desirable, without proper consideration of the contextual factors influencing their effectiveness. For example, da Villa and Panizzolo (1996) indicated that manufacturers' relationships with their suppliers have, in general, evolved during the 1990s towards partnership. They did not identify that some transactional relationships may still be appropriate in the supplier base. Similarly, Webster (1992) talked of a "clear evolution" away from arm's-length transactions towards partnerships, alliances, and networks. This overlooks that purchasing commodity items does not require the creation of close relationships. The risks associated with partnerships also seem to have been largely ignored in the literature (Spina and Zotteri, 2000).

A key question is: when are close relationships desirable? Researchers are now starting to investigate the contextual factors that make partnerships apposite and viable (e.g. McCutcheon and Stuart, 2000). Typically, a range of different relationships will be appropri- 
ate within the supplier base at any one time and Petroni and Panciroli (2002) recommended that the supplier base should be managed as a "portfolio" of relationships. Brennan (1997) highlighted the need to identify the product categories for which special relationships are necessary. An example from the automotive sector found that it is useful to classify and manage suppliers according to their involvement in new product development, the importance of their components in overall car performance, and the component lead time (Zirpoli and Caputo, 2002). Overall it can be seen that close relationships can bring advantages to manufacturers but this approach is not a panacea for the whole of the supplier base (Johnson et al, 2004).

\subsection{Building and maintaining close relationships}

Building relationships is one of the most difficult aspects of supply chain management (Johnson et al, 2004). McCutcheon and Stuart (2000) found that manufacturers should look at what they termed the "desirability" and the "feasibility" of partnership. The first factor is related largely to the technical capabilities of the supplier, and the match with a manufacturer's needs over time (including the technology development trajectory). Feasibility is connected with the two companies' views on the potential benefits, and the extent of goodwill and trust between them. Identification of the benefits for both parties is the foundation on which close, partnership-like relationships can be built. Zirpoli and Caputo (2002) identified a complex set of factors that are essential for the establishment of effective supplier relationships including: longterm contractual agreements to reduce uncertainty and support investments; suitable use of financial monitoring techniques such as target costing (to put enough focus on efficiency); and information sharing.

Once suitability has been verified, subtle management is required to grow a supplier into a full service provider. Full service provider means that the supplier provides excellent 
logistical and technical services (Petroni and Panciroli, 2002). Developing and maintaining high levels of trust has often been identified in the literature as an essential issue in relationships (e.g. Scott and Westbrook, 1991; Webster, 1992), but the operationalization of this concept is not simple. "Trust is not simply an input to a relationship; it is both a pre-requisite and an outcome of relationship development" (Johnson et al, 2004 p 26). Just as trust is important, ethical behaviour in the dyad has been identified as a prerequisite for successful long-term relationships (Carter, 2000). Related to the development of trust, several other researchers have stressed the need for both parties in the relationship to clarify expectations carefully. Landeros et al (1995) stated that expectations should be linked to performance measures.

Open communications are essential to successful co-operations (Stuart, 1997). Communications should include the sharing of not only production planning and control data (Spina and Zotteri, 2000) but also information on product innovation (Primo and Amundson, 2002). Carr and Pearson (1999) showed that communications should be frequent and cover strategic issues. Partnership-like relationships provide an atmosphere of trust where such open communications are possible. 
The time and mutual effort required to achieve close relationships should not be underestimated. Substantial resources are required to successfully manage partnership-like relationships (Dwyer et al., 1987; Simpson and Mayo, 1997). A (rare) longitudinal study, by Spina and Zotteri (2000), showed that negotiations on how the benefits of joint cost-saving programmes will be shared should best be conducted up-front. Subsequently, this allows the main efforts in the relationship to be focused on effective problem solving, rather than protracted discussions on how savings should be divided. Although this study was based on a single case, it does indicate the effort required of both parties and the inevitable problems that must be addressed in integrating operational and product development activities.

It is somewhat surprising that although close, partnership-like relationships have dominated how the supplier base has been viewed by both practitioners and academics over the last decade, the exact nature of such relationships is still unclear.

\subsection{The nature of close relationships}

In 1995 Wilson stated, "our knowledge about [supplier] relationships is at an early stage. We need to improve our concept definitions" (1995, p343). There has been research into supplier relationships over the past ten years but relatively little that sheds light on the nature of partnership-like relationships. The relationship between a manufacturer and supplier can take many forms and the distinguishing factors have been identified as the number of transactions, the longevity of the relationship, and the closeness.

Relationships have been perceived to be on a continuum ranging from purely discrete transactions, through repeated transactions, to long-term relationships, to full partnerships (Mohr and Nevin, 1990; Webster, 1992). Focusing only on the number of transactions ignores 
the fact that commodity components may be sourced regularly from a supplier without a close relationship being developed (or necessary).

Lambert et al. (1996) proposed that there are three kinds of partnerships, depending on their "short-term" (Type 1), "long-term" (Type 2) and "long-term with no-end" (Type 3) character (see Figure I). Although it is helpful to use the time dimension to differentiate between partnership types, in practice, it cannot be assumed that a manufacturer and supplier in a long-term relationship see themselves in partnership. It could be that the manufacturer has purchased the product from the supplier for several years due to a consistently low price and the relationship may not go anywhere beyond the placing of an order and its delivery. Therefore, the time dimension offers an insufficient explanation of partnerships but Lambert et al's diagram does indicate that joint ventures and other formal business relationships should be differentiated from how the term partnership is applied to supplier relationships.

\section{Take in Figure I}

"Closeness" has been widely identified as an important characteristic of relationships. Lambert et al. (1996) contended that partnerships are closer than other types of relationships, and Ellram (1991) defined partnerships in terms of "close sharing relationships." Similarly, Macbeth (1998) perceived partnerships as contrasting strongly with "distant relationships." According to Ford (1984), manufacturers and their suppliers emphasize close relationships and closeness can be explained in terms of five dimensions: geographical, the length of the relationship, technological, cultural, and social. Homburg (1995) argued that a clear definition of relationship closeness and a way of measuring the degree of closeness are lacking. Although a number of researchers agree that partnership-like relationships are close relation- 
ships, the opportunity for using closeness as the basis for an empirical investigation of relationships is open (Ellram, 1991; Saxton, 1997).

Several researchers have proposed definitions, or identified attributes of partnership-like relationships. These vary greatly in the attributes they identify, ranging from expressions of what they achieve (e.g. Landeros, et al., 1995), to vague concepts such as a "meeting of minds" (Ellram and Hendrick, 1995). For example, Brennan's definition is “partnership implies that: a single supplier now has a better understanding of the customer's requirements; the supplier has committed resources, financial, physical and human, to meeting the specific needs of the customer; the two partners operate more effectively with each other than with outsiders... the very fact of the existence of a partnership immediately implies some degree of mutual dependency... there are real economic advantages" (Brennan, 1997, pp769-770). This definition was based on the results of semi-structured interviews. Ellram and Hendrick (1995) took a different approach. Prior to their empirical investigation they defined partnership as "an on-going relationship between two firms that involves a commitment over an extended time period, and a mutual sharing of information and the risks and rewards of the relationship" (pp41-42). Table 1 summarizes the different views on the nature of partnership-like relationships in the literature - it covers papers which focused on supplier-manufacturer relationships and were published in operations management journals in the last ten years (mainly in the years following Wilson's statement that our knowledge of relationships is limited).

It can be seen from Table 1 that only two of the attributes in Ellram and Hendrik's definition correspond to those of Brennan. The variation in the attributes identified by different researchers lends support to our view that partnership-like relationships are context specific (and both practitioners and researchers have applied the term to quite a wide range of different relationships). 
Take in Table 1

Each of the attributes identified listed alphabetically in Table 1 has been given a reference number, e.g. " $\mathrm{L}_{3}$ " (which indicates the third attribute suggested by the literature). Commitment (L1), dependency (L5), the level of information sharing (L8), and the longevity of partnerships (L10) are the attributes that are most commonly identified (and these are highlighted in Table 1). The advantages resulting from partnership-like relationships-mainly price reduction, and quality and delivery performance improvements — are widely recognized. It can be seen that definitions sometimes mix the nature of partnership-like relationships with the advantages that such relationships can bring.

It should be noted that the research in six of the papers summarized in Table 1 did not empirically investigate the attributes of partnership directly. For example, McCutcheon and Stuart (2000) did not identify attributes empirically but operationalized the ones they chose in investigating the sorts of suppliers that are best suited for partnership. This type of approach is not unusual; Fynes and Voss (2002) also did not derive their attributes empirically but used them to investigate the influence of partnership on quality performance.

\subsection{Conclusions from the literature}

From the extant literature we conclude:

1) Partnership-like relationships are close co-operations between manufacturers and their suppliers, which bring many advantages including better quality, lower costs and reliable delivery;

2) Creating and maintaining such relationships is resource intensive; 
3) Partnership-like relationships are not appropriate for the whole of the supplier base;

4) A wide variety of attributes have been identified by different researchers. This indicates that partnership-like relationships are context dependent and not an absolute concept.

5) Much of our knowledge on the nature of supplier relationships is not backed with empirical evidence;

6) Since the term "partnership" has been used equivocally, a novel approach for investigating the nature of relationships is necessary. "Closeness" has potential as a vehicle for investigating partnership-like relationships.

\section{Methodology}

From the literature, it was clear that there is a need for an empirical study of the nature of supplier-manufacturer relationships and the research question for this exploratory study was:

- What do managers perceive as the main attributes of close manufacturer-supplier relationships?

In investigating relationships, researchers have typically used postal surveys with pre-defined notions of "partnerships" (e.g., Ellram and Hendrick, 1995; Saxton, 1997). Since different managers use the term partnership very differently, a further postal survey would risk collecting inaccurate or equivocal information. After empirical studies that have relied on large sample survey instruments (as indicated by Table 1), a new approach is required at this stage of theory development to provide additional insights and a fresh perspective.

In-depth interviews have been recognized as particularly useful in studying supplier relationships (McCutcheon and Stuart, 2000). However, previous interview-based research has 
shown that direct questioning has serious limitations for investigating relationships (Lemke et al., 2003). This is illustrated by Table 2, which classifies the answers from purchasing managers to a direct question on their relationships with suppliers. For example, fourteen simply answered that their relationships were "good" and nine that they were "partnerships" (ibid). There is a need to probe deeper than answers based on clichés, such as "partnerships". A new approach was needed to avoid the limitations of direct questioning and repertory grid technique was chosen, as it is a powerful research tool for probing interviewees' understanding of complex topics, particularly relationships.

\section{Take in Table 2}

\subsection{Repertory grid technique}

Repertory grid enables respondents to articulate their views on complex issues and pushes them beyond the use of jargon. It is particularly appropriate in studies where interviewees find it hard to articulate their opinions with clarity (Hussey and Hussey, 1997). The technique is a form of structured interviewing which was originally developed in the 1950s by the psychologist George Kelly. It is a highly effective tool for exploratory management research (Goffin, 2002).

To understand the technique, we will describe one grid elicited during our own research (from a manager in the electronics industry, coded Interviewee 16-2). The interviewee was asked to name nine suppliers with which they work, three in "close" relationships, three in "distant", and three in "average" relationships. Each of the suppliers' names was written on a separate postcard-sized card, which had been randomly numbered in advance. The interviewee was then presented with a random set of three cards (termed a "triad" in repertory grid 
terminology) and asked: "why is working with two of these suppliers similar and different from working with the third?" From the many combinations possible, triads should be selected to include strongly contrasting elements (Bender, 1974) and an explanation of this can be found in Goffin (2002.) The interviewee's response-termed a "construct"-was that one of the suppliers has reliable "delivery on-time", whereas the shipments from the other two were often "delayed". After this first construct was identified, each of the nine suppliers was rated against it on a 5-point scale [with 1 "very good", 3 "neutral", and 5 "very poor", as recommended by Tindall (1994), and Gammack and Stephens (1994)]. Further triads are used to identify additional constructs. Interviewees were not allowed to repeat constructs and so each new triad elicited a new construct, thus stimulating the interviewee to think more and more deeply about supplier relationships as the interview progressed. Care was taken to ensure that each construct was expressed in the form of a word or a phrase, whatever came most naturally to the respondent (Levy and Dugan, 1956). As each construct was identified, open-ended questions were used to probe its meaning so as to achieve a mutual understanding (Drew, 1995). Repertory grid technique allows meanings to be understood in an unbiased way as the discussions are based on the elements (i.e. suppliers) and the constructs (i.e. attributes of supplier relationships) raised by the interview themselves. The interviews were recorded so that close attention could be paid to the respondents' own explanations (Charmaz, 1995).

Take in Figure II

For every construct, the interviewee rated the nine suppliers' on the 1-5 rating scale and these ratings form the grid shown in Figure II. This shows that ten constructs were elicited from Interviewee 16-2, including "delivery on-time", "product quality" and "early informa- 
tion". The ratings of the elements on "early information" illustrate that the respondent differentiates strongly between the performances of each of their suppliers on this construct (ratings range from "1" for Suppliers 1 and 5, to "5" for Supplier 4). In contrast, the ratings of the elements on "product quality" illustrate that the respondent does not distinguish strongly between the performance of suppliers; the ratings only vary from "1" (e.g., Supplier 1) to "3" (e.g., Supplier 2). "Variability" is a mathematical measure of the spread of ratings on a particular construct that can be used to help identify more important constructs (Smith, 1986). Overall, repertory grid stimulates interviewees to think deeply about relationships and move beyond answers based on their immediate reactions and the use of jargon (especially as the term "partnership" was avoided).

\subsection{Sample}

Many German writers have acknowledged the importance of supplier management in Germany (e.g. Homburg, 1995; Nachtweh, 1998) and that close supplier relationships are a critical success factor (e.g. Boutellier and Alwin, 1996; Snijder, 1996). Therefore, Germany was chosen as a suitable national context in which to investigate supplier relationships (and one in which there has been little previous empirical research). The repertory grid interviews formed part of a larger programme of research into supplier management at German manufacturing companies and was linked to the International Best Factory Awards programme. This programme has been described previously (New and Szwejczewski, 1995) and has been the basis for a wide range of investigations of manufacturing performance. A previous study of supplier management took a database of 110 (mainly mid-sized) German manufactures as its starting point and then conducted telephone interviews with a stratified random sub-sample of 34 companies in three sectors (Lemke et al., 2000). In the current study, we contacted 28 of these 
companies (i.e. those in the electronics and engineering sectors) and 18 agreed to participate in the research (corresponding to a response of 64\%). The 18 companies represented German medium-sized companies, which had an average of 450 employees and an average turnover of 8.7 million Euros (approximately $\$ 8.7 \mathrm{M}$ ) and were deemed suitable as an exploratory sample. In engineering, the automotive industry was well represented as this is a major sector in Germany.

Take in Table 3

A multiple respondent approach is useful in research (Stuart, 1997) and so two or more respondents per company - normally the purchasing and production manager or managing director - were interviewed separately (see Table 3). (As many of the sample companies were small, the managing director often had responsibility for dealing with suppliers.) This matched well with repertory grid methodology, where it is normal to interview 30 or more people to identify a full set of constructs. It can be argued that manufacturers dominate the relationship with their suppliers, since they select suppliers and place orders. For this reason, the research at this stage focused exclusively on the views of managers from the manufacturer's side. Taking a dyadic approach and contrasting the views of manufacturers with those of suppliers would be a fertile area for further research.

\subsection{Analysis of data}

The grids and interview transcripts provided a rich pool of qualitative and quantitative data. The analysis was based on three steps (following recommendations in the methodology literature): 
- Collation of the common constructs. The verbal explanations of constructs (i.e., attributes) provided by each of the interviewees were analyzed. Two researchers (both fluent in German) reviewed the transcripts independently and interpreted the constructs. A high degree of correlation was found between the interpretations of the two researchers. Construct labels were defined, using where possible the most common terms from the respondents.

- Identification of full construct listing. Once the construct labels had been identified, this allowed identical constructs to be identified, and the frequency of mention of each construct was determined across the 39 interviews.

- Identification of key constructs. The combination of frequency and variability was used to identify the most important constructs.

\section{Results}

A native speaker conducted the interviews in the year 2000. Over forty-six hours of on-site interviews were conducted, using the repertory grid technique and semi-structured questions to collect background data. On average each interview elicited 10.54 constructs (more than would have resulted from direct questioning).

\subsection{Collation of common constructs}

From the 39 repertory grid interviews, a total of 411 constructs were elicited. Many of these were common, i.e. constructs that were mentioned by several respondents (e.g. "new product development"). To demonstrate how the constructs were collated, Table 4 gives two constructs with two example quotes from respondents and the assigned labels. The words underlined in each quote indicate how the construct labels were derived. 
It can be seen that the construct "flexibility" was elicited from 23 of the interviewees (59\% of total). From these quotes, it can be seen that the respondents themselves used the word "flexible". An analysis of the transcripts showed that all 23 respondents actually used the words "flexible" or "flexibility" and so the latter was chosen as a label.

Take in Table 4

The allocation of construct labels is not always as clear as in the case of flexibility. Respondents may use different terms in referring to the same issue and therefore the researcher must group these constructs under a suitable label. From Table 4 it can be seen that "Joint Problem Solving" was the label assigned to a construct mentioned by six respondents. From the example quotes it can be seen that one respondent referred to solving problems ‘jointly' whereas another referred to solving problems 'together'.

\subsection{Identification of full construct listing}

In summarizing the 411 constructs elicited, we have listed all 26 constructs that were mentioned by at least 5 respondents in Table 5. This also shows the frequency of mention and variability. The most commonly elicited construct was flexibility (from 23 respondents) followed by delivery performance (from 20 respondents). Each of the constructs (i.e. attributes) has been given a reference number, such as " $\mathrm{E}_{2}$ ", to designate it as an empirically derived attribute number two.

Take in Table 5 
It can be seen that the constructs elicited from respondents cover a range of factors. Some are related to the supplier's organization (e.g. size and capability); the relationship itself (e.g. its duration; whether it has a personal component or whether it is only business-related; how well it is maintained); the strategic value of the relationship to the manufacturer; and performance measures (e.g. quality and delivery performance). The wide range of attributes indicates the complexity of supplier relationships. Grouping the attributes into suitable categories could enhance our understanding of partnership-like relationships and we will return to this point later.

\subsection{Identification of key constructs}

The frequency count necessary for identifying important constructs is left open for interpretation in the repertory grid literature. Therefore, a decision was taken that a construct that has been mentioned by at least $25 \%$ of the respondents (i.e., by 10 or more) carries more importance in explaining supplier relationships than constructs less frequently mentioned constructs. The constructs that fulfil this requirement are indicated by their frequencies being highlighted in the third column of Table 5 and there are 14 important constructs (numbers 114) using the $25 \%$ criterion. In contrast, the bottom 12 constructs in the table, which were mentioned less than 10 times, are unlikely to be important ones.

Frequency is one indication of importance. Nevertheless, a high frequency of mention can also indicate that a construct was obvious and therefore readily mentioned. Variability is another indication of importance. A construct with a wide spread of ratings differentiates strongly between the elements and this spread (relative to the other constructs) is a construct's variability. The variability of the constructs in each grid was calculated using FlexiGrid 6; a software tool for analyzing individual grids. 
The variability measure is dependent on the number of constructs in an individual grid. For instance, if 5 constructs were elicited from a respondent, the average variability would be 20 per cent (i.e., 100/5), whereas if 10 constructs were elicited, the average variability would be 10 per cent. Therefore, the variability figures of constructs from grids with different numbers of constructs need to be normalized. This was done by multiplying the variability of each construct by the number of constructs in that individual grid divided by the average number of constructs across all of the respondents- 10.54 . The normalized variability figures for a construct were then averaged across the grids.

As there were on average 10.54 constructs elicited per interview, the average variability per construct was 9.49 (i.e. 100 / 10.54). A construct with an average normalized variability (ANV) greater than 9.49 means that the construct differentiates more strongly between the three supplier groups (i.e. close, average, and distant), while a construct with an ANV less than 9.49 indicates that the construct differentiates less strongly between the three supplier groups. The 14 constructs (numbers 3,4,6,7,8,9,11,12,13,16,19,23,24, and 25) that have higher than average variability are highlighted in the forth column of Table 6.

The construct "flexibility" $\left(\mathrm{E}_{1}\right)$ has a frequency of 23 but an ANV of 8.21. This shows that flexibility is readily mentioned by manufacturers but that most of their suppliers are flexible. In other words, the suppliers were rated similarly on the flexibility construct. The construct "special product capability" $\left(\mathrm{E}_{4}\right)$ has both a high frequency (17) and a high ANV (12.76) and so can be designated a key attribute. Using the combination of frequency and variability, nine key constructs were identified, as indicated by the right-hand column in Table 5 (construct numbers $3,4,6,7,8,9,11,12$ and 13). These are the attributes that most clearly differentiate between the suppliers where the relationship is close and those where it is distant. 
Several of the attributes in Table 5 raise interesting points: "flexibility" $\left(\mathrm{E}_{1}\right)$, delivery performance" $\left(\mathrm{E}_{2}\right)$, "quality" $\left(\mathrm{E}_{5}\right)$, and "price level" $\left(\mathrm{E}_{10}\right)$ are mentioned often but do not have high ANV (8.21; 6.83; 6.76; and 4.93 respectively). This finding shows that although these factors were mentioned by a large number of respondents, they do not differentiate strongly between the performance of each of the different suppliers. Another way of looking at this is that it indicates that the factors flexibility, delivery performance, quality and price are now hygiene factors and suppliers need to provide a full service and not just good performance on these factors. Another interesting result is "trust". This is often mentioned in the literature so it is surprising that it was only elicited empirically from two respondents (and so is not listed in Table 5, which only shows constructs from five or more respondents). A possible explanation for this is that trust is a high level attribute and the research has uncovered attributes on a deeper level that managers use as a proxy for trust. This would mean that the "trust" between a supplier and a manufacturer is perceived in terms of "personal relationship" $\left(\mathrm{E}_{3}\right)$, "relationship maintenance" $\left(\mathrm{E}_{8}\right)$ and "reliability" $\left(\mathrm{E}_{20}\right)$, although the German cultural context could be a contributory factor here). This appears to be an important area for future research.

\section{Discussion}

\subsection{Comparison of empirical evidence with the literature}

The current research identified a wide range of attributes, of which nine were identified to be particularly important in contrasting between close and other forms of supplier relationships. It is useful to further our understanding by comparing the empirically elicited factors to those in the extant literature.

Figure III is a Venn diagram of the attributes of supplier relationships from both the literature and the current study, with the key attributes highlighted. It can be seen that 12 attrib- 
utes are identified in the literature but were not found in the empirical investigation. These include "competitive advantage" $\left(\mathrm{L}_{2}\right)$ and "trust" $\left(\mathrm{L}_{18}\right)$, etc. This could be explained in that some of the terms used in the literature may not match the jargon used by practitioners. This demonstrates the confusion in the terminology of relationships - there is a need for unequivocal definitions of the attributes.

\section{Take in Figure III}

Eight attributes were identified in both the literature and this empirical study. These include "commitment" $\left(\mathrm{L}_{1} ; \mathrm{E}_{12}\right)$ and "delivery performance" $\left(\mathrm{L}_{4} ; \mathrm{E}_{2}\right)$. Two attributes that were identified in the literature were found in the empirical study to be particularly important: "dependency" $\left(\mathrm{L}_{5} ; \mathrm{E}_{6}\right)$ and "NPD and innovation" $\left(\mathrm{L}_{17} ; \mathrm{E}_{12}\right)$.

Nineteen attributes were identified in the research but were not in the literature. These include for example "flexibility" $\left(\mathrm{E}_{1}\right)$ and "location" $\left(\mathrm{E}_{14}\right)$. Obviously, there could be some linkage to the attributes in the literature, such as "co-operation" $\left(\mathrm{L}_{3}\right)$. However, our understanding of the terms in the literature is still too limited to draw such conclusions. The meanings of the empirically identified attributes are clear, since the repertory grid methodology elicited detailed explanations. Appendix A documents the meanings of the nine most important constructs, with example quotes from the respondents. Of these nine, only "dependency" $\left(\mathrm{L}_{5} ; \mathrm{E}_{6}\right)$ and "NPD and innovation" $\left(\mathrm{L}_{17} ; \mathrm{E}_{12}\right)$ were in the extant literature.

\subsection{A tentative conceptual model}

Although the comparison of the listings of attributes from this research to the extant literature discussed in Section 5.1 gives us some insights, Figure III does little to explain the interrela- 
tionships between the attributes listed. There is a need to categorize attributes and identify possible links between them. Figure IV shows a conceptual model of how supplier relationships develop, which is based on both the literature and our empirical study. This model classifies the multiplicity of attributes into five categories and takes ideas from the work of Fynes and Voss (2002) and McCutcheon and Stuart (2000).

\section{Take in Figure IV}

Before partnership is possible, selection is a necessary component. Based on the supplier's "competencies", selection is made and then detailed "communication" can take place. This communication leads to both "performance improvements" and "building trust". The performance "improvements" also support the building of trust and lead to short-term "returns" (e.g. quality improvements). As trust increases and time passes, "partnership-like relationships" can be achieved, which leads to greater rewards for both parties. It can be noted that each of the attributes of supplier relationships has been integrated into the model and the higher order constructs, such as "supplier's competences" have been linked to related, lower level, attributes.

The first of the higher order constructs — "supplier's competences" — is similar to "desirability" in McCutcheon and Stuart's terminology (2000). In our tentative model, "supplier's competences" includes well-known factors such as "quality" $\left(\mathrm{L}_{13} ; \mathrm{E}_{5}\right)$, "price" $\left(\mathrm{L}_{12}\right.$; $\left.\mathrm{E}_{10}\right)$ and "delivery performance" $\left(\mathrm{L}_{4} ; \mathrm{E}_{2}\right)$. Additionally, factors such as supplier flexibility and joint problem solving are important. However, two attributes of competence "special product capability" $\left(\mathrm{E}_{4}\right)$ and "new product development" $\left(\mathrm{L}_{17} ; \mathrm{E}_{12}\right)$ differentiate most strongly be- 
tween potential partners and non-partners and so this is indicated by the highlighting on Figure IV.

"Communication" is an enabler of trust and, in turn, partnership. The attributes of this high order construct include the "feedback" $\left(\mathrm{E}_{11}\right)$ and "information shared" $\left(\mathrm{L}_{8}\right)$ (both operational and strategic communications) being channelled through clearly "designated contacts" $\left(\mathrm{E}_{26}\right)$ in both companies. "Trust" is one of the most commonly discussed high order constructs of partnership in the literature but our research has indicated that it is related to factors such as "commitment" $\left(\mathrm{L}_{1} ; \mathrm{E}_{19}\right)$ and the "importance of the supplier" $\left(\mathrm{E}_{16}\right)$ to the manufacturer. The factors that most strongly characterize "trust" in partnerships are indicated by highlighting (e.g. "dependency"). "Partnership-like relationships" take time to achieve and are characterized for instance by "shared risks" $\left(\mathrm{L}_{14}\right)$ and active "relationship maintenance" $\left(\mathrm{E}_{8}\right)$.

\section{Conclusions}

\subsection{Limitations}

The sample was relatively small and not representative of German industry as a whole (e.g. it covered companies with an average size of 450 employees). Therefore, we need to be cautious in how we interpret the implications of the results. The research did not explore the supplier's view of relationships. A dyadic approach would almost certainly lead to more insights;

The analysis followed the recommendations in the repertory grid methodology literature and concentrated on identifying similarity - the important constructs from across the whole sample. Although outside the scope of this paper, the rich data could now be analyzed focusing on the differences between individuals' perceptions and the common ones of the sample.

The comparison of empirically derived attributes and those in the literature was prone to difficulty, as many of the terms in the literature have not been defined. This opens opportuni- 
ties for researchers to use techniques such as factor analysis to further our understanding. Similarly, the grouping of attributes to higher-level constructs is tentative and needs empirical verification.

Taking the limitations into account, we believe that the contribution of our research is that it both demonstrates the viability of a new method for investigating supplier relationships and provides exploratory data. The results have implications for both practice and research.

\subsection{Viable methodology}

The power of the repertory grid approach is illustrated by the contrast between the attributes of supplier relationships derived by direct questioning in previous research (Table 2) and those from repertory grid (Table 5). Table 2 shows that many respondents used the term partnership, which has already been identified in the literature as meaning different things to different people. Therefore, direct questioning has serious limitations in the study of supplier relationships. Even if follow-up questions had been used, direct questioning has a higher risk of introducing interviewer bias. Repertory grid technique produced extensive qualitative data on the meanings of interviews' terms and their rating of suppliers on the different attributes. It should be noted that 18 of the managers who were posed the direct question about their supplier relationships in a telephone interview were later personally interviewed using repertory grid technique and so the data for a one-to-one comparison of the results from the two approaches is available (although an analysis of this data is outside the scope of this paper).

\subsection{Key exploratory results}

Although the data are exploratory in nature, they help us to start to have a clearer understanding of relationships. Specifically Figure IV provides a tentative means for avoiding the confu- 
sion that has evolved in the literature and in practice about the nature of partnership-like relationships. It enables us to differentiate between the variety of conditions that lead to, affect or characterize close relationships.

The data clearly show that certain attributes of suppliers' performance are more important than others. For example, the data demonstrate that suppliers typically have similar performance levels on the factors "flexibility", "delivery performance", "quality", and "price". This empirically demonstrates that, to be successful, suppliers need to treat these as hygiene factors and concentrate on offering a full service. The results provide a clear explanation of the meanings of the attributes practitioners use to explain relationships (see the listing in the Appendix). Clarity in such terms is important if we are to avoid the type of confusion that has arisen around "partnership".

For most manufacturers the supplier base will consist of a portfolio of different relationships. A close relationship is not appropriate for every supplier. Recognizing this and prioritizing the resources needed for full partnership-like relationships is an aspect that emerges from our research but which needs further work.

\subsection{Implications for practitioners}

The literature extols the advantages of partnership-like relationships but, as shown in our review, such relationships require significant resources and are not always appropriate. The combination of insights from both the literature and our data has implications for both suppliers and manufacturers.

Only certain suppliers should be selected for the development of partnership-like relationships. The selection criteria should be based on both the components involved and the

supplier's competences (particularly their capability to contribute to new product develop- 
ment and special products), as indicated by Figure IV. It is important to note that some of these criteria had not been identified in the literature before but obviously a wider sample is required to confirm the importance of these factors. Establishing whether a supplier really has the necessary competences should reduce the risk of investing significant resources in developing the relationship, only to find that the supplier is unsuitable. Figure IV also indicates the type of communications that need to be established and how mutual trust should be achieved. The identification of attributes which clearly differentiate close relationships is useful information for manufacturers looking to optimize the management of the portfolio of relationships in their supplier base.

The results show that suppliers cannot rely solely on offering high quality products, delivering them on-time and at a reasonable price, if their strategy is to be more than a commodity supplier. In order to be attractive to a manufacturer, suppliers need to ensure that they are able to offer a range of "competences". Once selected, Figure IV indicates the areas on which they should concentrate in communications and building trust. The wide range of factors to be considered is important.

\subsection{Implications for researchers}

The authors believe that the study has unearthed a rich vein for further study. The key topics are:

- The results of our research urgently need to be verified using a wider, representative sample (and, if required, copies of the repertory grid data collection instruments are available from the authors);

- There is a need to look for differences in the dyad, i.e. how suppliers view the selection and partnership development process; 
- The selection criteria for potential partners need to be understood better. Conjoint analysis could be used to understand the trade-offs manufacturers make in choosing their partners. The particular importance of the two factors "special products" and "new product development" indicated by repertory grid analysis could then be verified;

- Only one case study has previously investigated the longitudinal aspects of developing partnerships (Spina and Zotteri, 2000). The framework offered by Figure IV could be investigated using a longitudinal case study approach. This could lead to a better understanding of the complex process of transforming transactional relationships into partnership-like ones;

- A "portfolio" of relationships is appropriate in the supplier base (Petroni and Panciroli, 2002). Empirical evidence is needed on the number of transactional relationships ("distant"), "average" relationships, "relationships in development" and "partnership-like relationships" which are typically found in manufacturers' portfolios. This research has previously not been viable as the understanding of "partnership" has been too ambiguous;

- The cultural context of Germany may well have influenced the results. Therefore, as the viability of the methodology for investigating the complex topic of supplier-manufacturer partnerships has been demonstrated, replication is required in the US and other countries with a strong manufacturing base.

For too long our knowledge of manufacturer-supplier relationships has been clouded by the equivocal use of the term "partnership". We believe that this paper has made a contribution to the understanding of what is one of the most challenging aspects of supply chain management—developing an appropriate set of relationships with suppliers. However, much still remains to be done. 


\section{Acknowledgements}

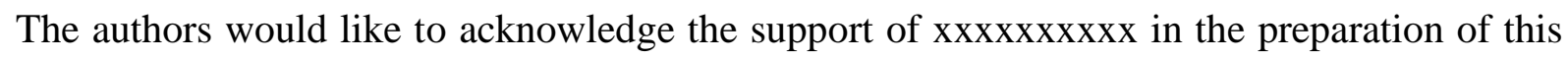

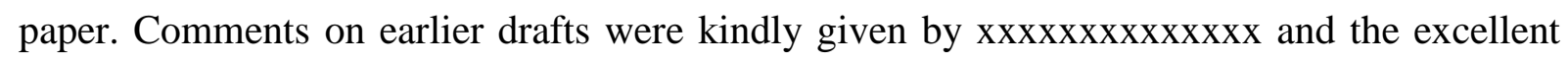

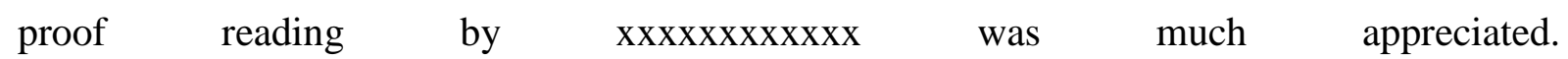

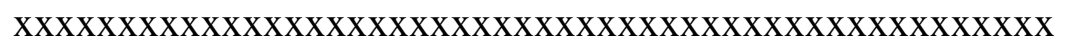




\section{Appendix A}

Meanings of the Most Important Constructs (in alphabetical order).

\begin{tabular}{|c|c|c|c|}
\hline No. & Key Construct & Explanation & Example quotes \\
\hline $\mathrm{E}_{13}$ & Complaint Handling & $\begin{array}{l}\text { Good handling of complaints (1) - The } \\
\text { supplier accepts faults in a product, } \\
\text { reacts quickly, and eliminates the fault } \\
\text { once and for all. Poor handling of } \\
\text { complaints (5) - The manufacturer has } \\
\text { to convince the supplier that the prod- } \\
\text { uct is faulty. He reacts slowly and } \\
\text { supposedly eliminated faults reappear } \\
\text { in the future. }\end{array}$ & $\begin{array}{l}\text { "While certain suppliers need to be per- } \\
\text { suaded that the part they have sent me yes- } \\
\text { terday is faulty, others sent out the re- } \\
\text { placement even before they start analysing } \\
\text { the actual fault. Some are simply good at } \\
\text { complaint handling; others are really poor } \\
\text { at it." } \\
\text { (Quality manager; Electronics) }\end{array}$ \\
\hline $\mathrm{E}_{6}$ & Dependency & $\begin{array}{l}\text { Independent (1) - The manufacturer } \\
\text { has got the opportunity to switch to } \\
\text { alternative suppliers in the short-term. } \\
\text { The market is a buyer-market based on } \\
\text { open competition. Dependent (5) - } \\
\text { Switching to another supplier is time } \\
\text { consuming as the supplier has got a } \\
\text { monopoly (sellers' market). }\end{array}$ & $\begin{array}{l}\text { "Although I am not happy with this sup- } \\
\text { plier, I have no alternative. We are at a } \\
\text { point were we think about developing an } \\
\text { 'alternative supplier' in order to switch } \\
\text { later; but this requires investment. In some } \\
\text { situations I prefer to be independent, be- } \\
\text { cause I usually get a better price." } \\
\text { (Purchasing manager; Engineering) }\end{array}$ \\
\hline $\mathrm{E}_{11}$ & Feedback & $\begin{array}{l}\text { Fast Feedback (1) - the conversational } \\
\text { supplier replies to all enquiries of the } \\
\text { manufacturer promptly. No Feedback } \\
(5) \text { - there is a 'silent atmosphere' } \\
\text { between the supplier and manufacturer } \\
\text { and the supplier does not reply to the } \\
\text { manufacturer's enquiries. The manu- } \\
\text { facturer has to 'run after' the supplier, } \\
\text { as he does not reply to the manufac- } \\
\text { turer's enquiries. }\end{array}$ & $\begin{array}{l}\text { "This supplier replies to all my enquiries. } \\
\text { Even if I leave a message on his voice-mail, } \\
\text { he promptly returns my call and gives me } \\
\text { an answer. Other suppliers don't seem to } \\
\text { see the point in answering my questions- } \\
\text { they don't give me any feedback at all” } \\
\text { (Quality manager; Engineering) }\end{array}$ \\
\hline $\mathrm{E}_{12}$ & $\begin{array}{l}\text { New Product } \\
\text { Development / } \\
\text { Innovation }\end{array}$ & $\begin{array}{l}\text { New product development (1) - The } \\
\text { supplier becomes involved in develop- } \\
\text { ing and enhancing products due to his } \\
\text { high quality technical input. No new } \\
\text { product development (5) - In new } \\
\text { product development processes, the } \\
\text { manufacturer does not consider the } \\
\text { supplier to take part. In general, the } \\
\text { supplier is unable to submit any tech- } \\
\text { nical input and he has not the farsight- } \\
\text { edness for new products. }\end{array}$ & $\begin{array}{l}\text { "This supplier has good ideas for develop- } \\
\text { ing new ideas and we are keen to involve } \\
\text { him in our NPD processes. The other two } \\
\text { suppliers are not innovative and we don't } \\
\text { involve them in our own NPD processes." } \\
\text { (Managing Director; Engineering) }\end{array}$ \\
\hline $\mathrm{E}_{7}$ & Organizational Size & $\begin{array}{l}\text { Small Family Enterprise (1) - The } \\
\text { supplying organisation consists of a } \\
\text { small number of employees and is } \\
\text { family-owned. Big Enterprise (5) - } \\
\text { The organisation has often more than } \\
500 \text { employees and has many subsidi- } \\
\text { aries (worldwide), e.g., a full public } \\
\text { company. }\end{array}$ & $\begin{array}{l}\text { “Our suppliers vary in sizes. It starts with } \\
\text { small firms run by a family plus } 2 \text { or } 3 \text { addi- } \\
\text { tional employees. This can go up to big en- } \\
\text { terprises that act globally and that are rep- } \\
\text { resented on the stock market." } \\
\text { (Purchasing manager; Engineering) }\end{array}$ \\
\hline $\mathrm{E}_{8}$ & $\begin{array}{l}\text { Relationship } \\
\text { Maintenance }\end{array}$ & $\begin{array}{l}\text { Active }(1)-\text { The relationship is very } \\
\text { interactive and the supplier as well as } \\
\text { the manufacturer nurture their rela- } \\
\text { tionship by contacting the partner and } \\
\text { visiting the partner's company on a } \\
\text { regular basis. None }(5) \text { - Neither the } \\
\text { supplier nor the manufacturer nurture }\end{array}$ & $\begin{array}{l}\text { "With partners we have frequent meetings } \\
\text { to discuss various business issues; the sup- } \\
\text { pliers take an active role in this. By con- } \\
\text { trast, many suppliers are very inactive - I } \\
\text { even would describe them as passive." } \\
\text { (Managing Director; Electronics) }\end{array}$ \\
\hline
\end{tabular}




\begin{tabular}{|c|c|c|c|}
\hline No. & Key Construct & Explanation & Example quotes \\
\hline & & $\begin{array}{l}\text { the relationship. The supplier initially } \\
\text { aimed at an easy ‘customer catch' and } \\
\text { he does not develop the relationship to } \\
\text { anything more than that. }\end{array}$ & \\
\hline $\mathrm{E}_{4}$ & $\begin{array}{l}\text { Special Product } \\
\text { Capability }\end{array}$ & 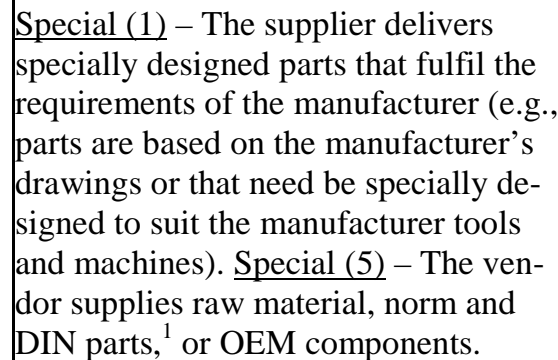 & $\begin{array}{l}\text { "This supplier delivers special customer } \\
\text { specific parts and delivers them to us exclu- } \\
\text { sively. They are tailor-made. The other two } \\
\text { suppliers deliver standard parts which they } \\
\text { also deliver to other customers" } \\
\text { (Managing Director; Electronics). }\end{array}$ \\
\hline $\mathrm{E}_{3}$ & $\begin{array}{l}\text { Personal Relation- } \\
\text { ship }\end{array}$ & $\begin{array}{l}\text { Personal (1) - There exists an inten- } \\
\text { sive and familiar contact between the } \\
\text { supplier and manufacturer at a 'human } \\
\text { level.' Both parties have an interest to } \\
\text { establish the personal relationship fur- } \\
\text { ther and to keep it that way. Business } \\
\text { (5) - The relationship between the } \\
\text { supplier and manufacturer is formal, } \\
\text { impersonal and superficial and purely } \\
\text { aims at processing orders. }\end{array}$ & $\begin{array}{l}\text { "To many suppliers I have a distant con- } \\
\text { tact. I only know them from telephone con- } \\
\text { versations - I place an order and I get it } \\
\text { delivered. That is very business-like and } \\
\text { there is not more to it. To some suppliers, } \\
\text { however, it happens that we establish a per- } \\
\text { sonal relationship. This goes beyond the } \\
\text { pure business relationship as we can talk } \\
\text { about private matters." } \\
\text { (Managing Director; Electronics) }\end{array}$ \\
\hline $\mathrm{E}_{9}$ & $\begin{array}{l}\text { Volume of Turnover } \\
\text { as bought from the } \\
\text { supplier }\end{array}$ & $\begin{array}{l}\text { High (1) - The supplier delivers a high } \\
\text { volume of turnover to the manufac- } \\
\text { turer over the year and he is one of the } \\
\text { main suppliers. The manufacturer de- } \\
\text { scribes the supplier as his 'A-supplier.' } \\
\text { Low (5) - Either the supplier delivers } \\
\text { parts sporadically or he supplies } \\
\text { merely low volumes over the year ('C- } \\
\text { supplier'). }\end{array}$ & $\begin{array}{l}\text { "We have a number of suppliers that deliver } \\
\text { low volumes; these are our C-suppliers. The } \\
\text { A-suppliers that deliver high volumes are } \\
\text { the other extreme. Other suppliers are } \\
\text { somewhat in-between." } \\
\text { (Purchasing manager; Electronics) }\end{array}$ \\
\hline
\end{tabular}

\footnotetext{
${ }^{1}$ DIN is a German Industrial Standard, similar to ASA in the US.
} 


\section{References}

1) Bender, M.P., 1974. "Provided versus Elicted Constructs: An Explanation of Warr and Coffman's Anomalous Finding." British Journal of Social and Clinical Psychology, Vol. 13, pp.329-330.

2) Boutellier, R. and Alwin L., 1996. "Integration von Beschaffungslogistik und Produktentwicklung”, in Schuh, G., Weber, H. and Kajüter, P., Logistikmanagement: Strategische Wettbewerbsvorteile durch Logistik, Schäffer-Poeschel Verlag, Stuttgart, pp. 253-273.

3) Brennan, R., 1997. "Buyer/Supplier Partnering in British Industry: The Automotive and Telecommunications Sectors”. Journal of Marketing Management, vol. 13, no. 8, November, pp. 759-775.

4) Carr, A.S. and Pearson, J.N., 1999. "Strategically Managed Buyer-Supplier Relationships and Performance Outcomes”. Journal of Operations Management, vol. 17, pp. 497-519.

5) Carter, C.R., 2000. "Ethical Issues in International Buyer-Supplier Relationships: A Dyadic Examination”. Journal of Operations Management, vol. 18, no. 2, February, pp. 191-208.

6) Charmaz, K., 1995. "Grounded Theory", in Smith, J.A., Harré, R. and Langenhove, L. (Eds.), Rethinking Methods in Psychology, Sage, London, pp. 27-49.

7) Da Villa, F. and Panizzolo, R., 1996. "Buyer-Subcontractor Relationships in the Italian Clothing Industry: An Interpretive Framework”. International Journal of Operations \& Production Management, vol. 16, no. 7, pp. 38-61. 
8) Drew, P., 1995. "Conversation Analysis", in Smith, J.A., Harré, R. and Langenhove, L. (Eds.), Rethinking Methods in Psychology, Sage, London, pp. 64-79.

9) Dwyer, F.R., Schurr, P.H. and Oh, S. 1987. "Developing Buyer-Seller Relationships". Journal of Marketing, Vol. 51, no. 2, pp. 11-27.

10) Ellram, L.M., 1991. "Life-Cycle Patterns in Industrial Buyer-Seller Partnerships". International Journal of Physical Distribution \& Logistics Management, vol. 21 no. 9, pp. $12-21$.

11) Ellram, L.M. and Hendrick, T.E., 1995. "Partnering Characteristics: A Dyadic Perspective”. Journal of Business Logistics, vol. 16, no. 1, pp. 41-64.

12) Ford, D., 1984. "Buyer/Seller Relationships in International Industrial Markets". Industrial Marketing Management, vol. 13, no. 2, May, pp. 101-112.

13) Fretty, P., 2001. "Partnering Pays", Industrial Distribution, vol. 90, no. 5, p. 13.

14) Fynes, B. and Voss, C., 2002. "The moderating effect of buyer-seller relationships on quality practice and performance". International Journal of Production and Operations Management, vol. 22, no. 6, pp. 589-613.

15) Gammack, J.G. and Stephens, R.A., 1994. "Repertory Grid Technique in Constructive Interaction", in Cassell, C. and Symon, G. (Eds.), Qualitative Methods in Organizational Research: A Practical Guide, Sage, London, pp. 72-90.

16) Gentry, J.J., 1996. "Carrier Involvement in Buyer-Supplier Strategic Partnerships". International Journal of Physical Distribution \& Logistics Management, vol. 26, no. 3, pp. $14-25$.

17) Goffin, K., 2002. "Repertory Grid Technique”, in Partington, D. (Ed.), "Essential Skills for Management Research”, Sage, London, pp. 199-225. 
18) Goffin, K. Szwejczewski, M. and New, C., 1997. "Managing Suppliers: When Fewer Can Mean More". International Journal of Physical Distribution \& Logistics Management, vol. 27, no. 7, pp. 422-436.

19) Graham, T.S., Daugherty, P.J. and Dudley, W.N. 1994., "The Long-Term Strategic Impact of Purchasing Partnerships". International Journal of Purchasing and Materials Management, vol. 30, no. 4, pp. 13-18.

20) Homburg, C., 1995. "Closeness to the Customer in Industrial Markets: Towards a Theory-Based Understanding of Measurement, Organizational Antecedents, and Performance Outcomes”. Zeitschrift für Betriebswirtschaft, vol. 65, no. 3, pp. 309-331.

21) Hussey, J. and Hussey, R., 1997. "Business Research”, Macmillan Press, London.

22) Johnson, D.A., McCutcheon, D.M., Stuart, F.I. and Kerwood, H., 2004. "Effect of Supplier Trust on Performance of Cooperative Supplier Relationships". Journal of Operations Management, vol. 22, pp. 23-38.

23) Kerns, C.D., 2000. "Strengthen Your Business Partnership: A Framework and Application”. Business Horizons, vol. 43, no. 4, pp. 17-22.

24) Lambert, D.M., Emmelhainz, M.A. and Gardner, J.T., 1996. "Developing and Implementing Supply Chain Partnerships", International Journal of Logistics Management, vol. 7 , no. 2 , pp. 1-17.

25) Landeros, R., Reck, R. and Plank, R.E., 1995. "Maintaining Buyer-Supplier Partnerships”, International Journal of Purchasing and Materials Management, vol. 31, no. 3, pp. 3-11.

26) Lemke, F., Goffin, K. and Szwejczewski, M., 2003. "Investigating the Meaning of Supplier-Manufacturer Partnerships: An Exploratory Study". International Journal of Physical Distribution \& Logistics Management, vol. 33, no. 1, pp.12-35. 
27) Lemke, F., Goffin, K., Szwejczewski, M., Pfeiffer, R. and Lohmüller, B., 2000 “Supplier Base Management: Experiences from the UK and Germany”. International Journal of Logistics Management, vol. 11, no. 2, pp. 45-58.

28) Levy, L.H. and Dugan, R.D., 1956. “A Factorial Study of Personal Constructs”. Journal of Consulting Psychology, vol. 20, no. 1, pp. 53-57.

29) Macbeth, D., 1998. "Partnering - Why Not?" The Second Worldwide Research Symposium on Purchasing and Supply Chain Management, London, England, pp. 351-362.

30) Masella, C. and Rangone, A., 2000. "A contingent approach to the design of vendor selection systems for different types of co-operative customer/supplier relationships". International Journal of Production and Operations Management, vol. 20, no. 1, pp. 70-81.

31) McCutcheon, D. and Stuart, F.I., 2000. "Issues in the Choice of Supplier Alliance Partners". Journal of Operations Management, vol. 18, pp. 279-301.

32) Metcalf, L.E., Frear, C.R. and Kirshnan, R., 1992. "Buyer-Seller Relationships: An Application of the IMP Interaction Model”, European Journal of Marketing, vol. 26, no. 2, pp. 27-46.

33) Mohr, J. and Nevin, J.R., 1990. "Communication Strategies in Marketing Channels: A Theoretical Perspective". Journal of Marketing, vol. 54, pp. 36-51.

34) Monczka, R.M., Trent, R.J. and Callahan, T.J., 1993. "Supply base strategies to maximize supplier performance", International Journal of Physical Distribution \& Logistics Management, vol. 23, no. 4, pp. 42-54.

35) Nachtweh, K.P., 1998. "Das Umfeld des Einkaufs: Prozeß- und zielorientierte Lieferantenauswahl”. Beschaffung Aktuell, no. 2, pp. 41-43. 
36) New, C. and Szwejczewski, M., 1995. "Performance Measurement and the Focused Factory: Empirical Evidence”. International Journal of Operations \& Production Management, vol. 15, no. 4, pp. 63-79.

37) O'Toole, T. and Donaldson, B., 2002. "Relationship Performance Dimensions of Buyer-Supplier Exchanges”. European Journal of Purchasing \& Supply Management, vol. 8 , pp. 197-2002.

38) Petroni, A. and Panciroli, B., 2002. 'Innovation as a Determinant of Suppliers' Roles and Performances: An Empirical Study in the Food Machinery Industry”. European Journal of Purchasing \& Supply Management, vol. 8, no. 3, pp.135-149.

39) Primo, M.A.M. and Amundson, S.D., 2002. "An Exploratory Study of Supplier Relationships on New Product Development Outcomes". Journal of Operations Management, vol. 20, no. 1, February, pp. 33-52.

40) Rommel, G., 1991. "The secrets of German competitiveness". The McKinsey Quarterly, no. 3 , pp. $40-54$.

41) Saxton, T., 1997. "The Effects of Partner and Relationship Characteristics on Alliance Outcomes". Academy of Management Journal, vol. 40, no. 2, pp. 443-461.

42) Scott, C. and Westbrook, R., 1991. "New strategic tools for supply chain management". International Journal of Physical Distribution \& Logistics Management, vol. 21, no. 1, pp. 23-33.

43) Simpson, J.T. and Mayo, D.T., 1997. "Relationship Management: A Call for Fewer Influence Attempts?”. Journal of Business Research, vol. 39, no. 3, pp. 209-218.

44) Smith, M., 1986. "An Introduction to Repertory Grids - Part One”. Graduate Management Research, vol. 3, no. 1, pp. 4-17. 
45) Snijder, J., 1996. "Global Sourcing - weltweite Einkaufsmarktaufklärung und Lieferantenauswahl“, in: Schuh, Günther, Hubert Weber and Peter Kajüter, Logistikmanagement: Strategische Wettbewerbsvorteile durch Logistik, SchäfferPoeschel Verlag, Stuttgart, pp. 241-252.

46) Spina, G. and Zotteri, G., 2000. "The Implementation Process of Customer-Supplier Partnership: Lessons From A Clinical Perspective”. International Journal of Operations \& Production Management, vol. 20, no. 10, pp. 1164-1182.

47) Stuart, F.I., 1997. "Supplier alliance success and failure: a longitudinal dyadic perspective”. International Journal of Production and Operations Management, vol. 17, no. 6, pp. 539-557.

48) Tindall, C., 1994. "Personal Construct Approaches", in Banister, P., Burman, E., Parker, I., Taylor, M. and Tindall, C. (Eds.), Qualitative Methods in Psychology: A Research Guide, Open University Press, Buckingham, pp. 72-91.

49) Webster, F.E., 1992. "The Changing Role of Marketing in the Corporation". Journal of Marketing, vol. 56, pp. 1-17.

50) Wilson, D.T., 1995. "An Integrated Model of Buyer-Seller Relationships". Journal of the Academy of Marketing Science, vol. 23, no. 4, Fall, pp. 335-345.

51) Ziropli, F. and Caputo, M., 2002. "The nature of buyer-supplier relationships in codesign activities: The Italian auto industry case". International Journal of Production and Operations Management, vol. 22, no. 12, pp. 1389-1410. 
Table 1: Summary of the views on the 'partnership' concept found in research from 1990-2003.

\begin{tabular}{|c|c|c|c|c|c|c|}
\hline Investigation & Brennan (1997) & $\begin{array}{c}\text { Ellram and Hendrick } \\
(1995)\end{array}$ & $\begin{array}{c}\text { Fynes and Voss } \\
(2002)\end{array}$ & Graham et al (1994) & Gentry (1996) & $\begin{array}{c}\text { Masella and Rangone } \\
(\mathbf{2 0 0 0 )}\end{array}$ \\
\hline Specific definition given? & $\begin{array}{c}\text { Yes } \\
(\text { pp769-770; see text) }\end{array}$ & $\begin{array}{c}\text { Yes } \\
\text { (pp41-42; see text) }\end{array}$ & No & $\begin{array}{l}\text { Yes } \\
(\mathrm{p} 14)\end{array}$ & No & No \\
\hline Empirical determination of attributes? & Yes & $\begin{array}{c}\text { Yes } \\
\text { (definition tested) }\end{array}$ & $\begin{array}{c}\text { No } \\
\text { (investigated the influ- } \\
\text { ence of partnership on } \\
\text { quality) }\end{array}$ & Yes & Yes & $\begin{array}{c}\text { No } \\
\text { (investigated the sup- } \\
\text { plier selection needed } \\
\text { for partners) }\end{array}$ \\
\hline Methodology used & $\begin{array}{l}\text { Semi-structured } \\
\text { interviews } \\
15 \text { dyads (buyer's } \\
\text { and supplier's). } \\
\text { UK automotive / } \\
\text { telecomms. }\end{array}$ & $\begin{array}{l}\text { Mail survey } \\
\text { 80 dyads re- } \\
\text { sponded } \\
\quad \text { Sectors: air trans- } \\
\text { port, banking, com- } \\
\text { munications, food, } \\
\text { hotels, trucking etc. }\end{array}$ & N/A & $\begin{array}{l}\text { Mail survey (162 } \\
\text { responses). } \\
\text { Purchasing man- } \\
\text { agers (single in- } \\
\text { formant) } \\
\text { - USA manufactur- } \\
\text { ing' }\end{array}$ & $\begin{array}{ll}\text { Interviews } \\
\text { Five 3-way inter- } \\
\text { views - buyers, } \\
\text { suppliers and a } \\
\text { carrier. } \\
\text { Automotive, bicy- } \\
\text { cle, pet food, dis- } \\
\text { count retailing } \\
\text { consumer goods, } \\
\text { railroad manufac- } \\
\text { turing). }\end{array}$ & N/A \\
\hline \multicolumn{7}{|l|}{ Ref. /Attributes of Partnership Identified } \\
\hline $\mathrm{L}_{1}$ Commitment including resources & $\bar{v}$ & $\checkmark$ & $\checkmark$ & & & $\checkmark$ \\
\hline $\mathrm{L}_{2}$ Competitive advantage / strategic & & & & & & $\checkmark$ \\
\hline $\mathrm{L}_{3}$ Co-operation & $\checkmark$ & & $\checkmark$ & & $\checkmark$ & \\
\hline $\mathrm{L}_{4}$ Delivery performance & $\checkmark$ & $\checkmark$ (implicitly) & $\checkmark$ & $\checkmark$ & $\checkmark$ (implicitly) & $\checkmark$ (implicitly) \\
\hline $\mathrm{L}_{5}$ Dependency / mutual advantage & $\checkmark$ & $\checkmark$ & $\bar{v}$ & & & \\
\hline \multicolumn{7}{|l|}{$\mathrm{L}_{6}$ Exchange of resources } \\
\hline $\mathrm{L}_{7}$ Focus on solving problems / performance & & & & & $\checkmark$ & \\
\hline $\mathrm{L}_{8}$ Information sharing / communication & & $\checkmark$ & $\checkmark$ & $\checkmark$ & $\checkmark$ & \\
\hline $\mathrm{L}_{9}$ Integration of logistics & & & & & & $\checkmark$ \\
\hline $\mathrm{L}_{10}$ Long-term & & $\checkmark$ & & $\checkmark$ & $\checkmark$ & $\checkmark$ \\
\hline \multicolumn{7}{|l|}{$\mathrm{L}_{11}$ Non-tender price agreement } \\
\hline $\mathrm{L}_{12}$ Price reduction & $\checkmark$ & $\checkmark$ (implicitly) & $\checkmark$ & $\checkmark$ & $\checkmark$ (implicitly) & $\checkmark$ (implicitly) \\
\hline $\mathrm{L}_{13}$ Quality improvement & $\checkmark$ & $\checkmark$ (implicitly) & $\checkmark$ & $\checkmark$ & $\checkmark$ (implicitly) & $\checkmark$ (implicitly) \\
\hline $\mathrm{L}_{14}$ Sharing risks / rewards & & & & $\checkmark$ & $\checkmark$ & \\
\hline $\mathrm{L}_{15}$ Single or limited number of suppliers & $\checkmark$ & & & & & \\
\hline \multicolumn{7}{|l|}{$\mathrm{L}_{16}$ Training of supplier } \\
\hline $\mathrm{L}_{17}$ Technology / innovation exchange & & & & & & $\checkmark$ \\
\hline $\mathrm{L}_{18}$ Trust & & & $\checkmark$ & & & \\
\hline \multicolumn{7}{|l|}{$\mathrm{L}_{19}$ Value of resource access } \\
\hline $\mathrm{L}_{20}$ Voluntary & & & & $\checkmark$ & & \\
\hline
\end{tabular}




\begin{tabular}{|c|c|c|c|c|c|}
\hline Investigation & $\begin{array}{l}\text { McCutcheon and } \\
\text { Stuart (2000) }\end{array}$ & $\begin{array}{c}\text { Petroni and } \\
\text { Panciroli } \\
\text { (2002) }\end{array}$ & $\begin{array}{c}\text { Saxton } \\
(1997)\end{array}$ & $\begin{array}{c}\text { Spina and Zotteri } \\
(\mathbf{2 0 0 0 )}\end{array}$ & $\begin{array}{l}\text { Webster } \\
\text { (1992) }\end{array}$ \\
\hline Specific definition given? & $\begin{array}{c}\text { Yes } \\
(\mathrm{p} 285 ; \text { see text })\end{array}$ & No & No & $\begin{array}{c}\text { Yes } \\
(\mathrm{p} 1165) \\
\end{array}$ & $\begin{array}{l}\text { Yes } \\
(\mathrm{p} 5) \\
\end{array}$ \\
\hline $\begin{array}{l}\text { Empirical determination of attrib- } \\
\text { utes? }\end{array}$ & $\begin{array}{c}\text { No } \\
\text { (investigated how to } \\
\text { choose partners) }\end{array}$ & $\begin{array}{c}\text { No } \\
\text { (investigated partner- } \\
\text { ship and innovation) }\end{array}$ & Yes & $\begin{array}{l}\text { No } \\
\text { (investigated the longi- } \\
\text { tudinal development of } \\
\text { partnership) }\end{array}$ & $\begin{array}{c}\text { No } \\
\text { (conceptual paper) }\end{array}$ \\
\hline Methodology used & N/A & N/A & $\begin{array}{l}\text { Mail survey } \\
\text { - } 137 \text { companies } \\
\text { - UK, USA, Cana-da, } \\
\text { Germany, etc. } \\
\text { - Chemical products }\end{array}$ & N/A & N/A \\
\hline \multicolumn{6}{|l|}{$\begin{array}{l}\text { Ref. /Attributes of Partnership Iden- } \\
\text { tified }\end{array}$} \\
\hline $\mathrm{L}_{1}$ Commitment including resources & & & & $\checkmark$ & \\
\hline $\mathrm{L}_{2}$ Competitive advantage / strategic & $\checkmark$ & & & & \\
\hline \multicolumn{6}{|l|}{$\mathrm{L}_{3}$ Co-operation } \\
\hline $\mathrm{L}_{4}$ Delivery performance & $\checkmark$ & $\checkmark$ & $\checkmark$ (implicitly) & $\checkmark$ & $\checkmark$ \\
\hline $\mathrm{L}_{5}$ Dependency / mutual advantage & $\checkmark$ & $\checkmark$ & & & $\checkmark$ \\
\hline $\mathrm{L}_{6}$ Exchange of resources & & $\checkmark$ & $\checkmark$ & & \\
\hline $\begin{array}{l}\mathrm{L}_{7} \text { Focus on solving problems / per- } \\
\text { formance }\end{array}$ & $\checkmark$ & & & $\checkmark$ & \\
\hline $\begin{array}{l}\mathrm{L}_{8} \text { Information sharing / communica- } \\
\text { tion }\end{array}$ & $\checkmark$ & $\checkmark$ & & $\checkmark$ & \\
\hline \multicolumn{6}{|l|}{$\mathrm{L}_{9}$ Integration of logistics } \\
\hline $\mathrm{L}_{10}$ Long-term & $\checkmark$ & $\checkmark$ & & $\checkmark$ & \\
\hline $\mathrm{L}_{11}$ Non-tender price agreement & & $\checkmark$ & & & \\
\hline $\mathrm{L}_{12}$ Price reduction & $\checkmark$ & $\checkmark$ & $\checkmark$ (implicitly) & $\checkmark$ & $\checkmark$ \\
\hline $\mathrm{L}_{13}$ Quality improvement & $\checkmark$ & $\checkmark$ & $\checkmark$ (implicitly) & $\checkmark$ & $\checkmark$ \\
\hline $\mathrm{L}_{14}$ Sharing risks / rewards & $\checkmark$ & & $\checkmark$ & & \\
\hline $\begin{array}{l}\mathrm{L}_{15} \text { Single or limited number of suppli- } \\
\text { ers }\end{array}$ & & & & $\checkmark$ & \\
\hline $\mathrm{L}_{16}$ Training of supplier & & $\checkmark$ & & & \\
\hline $\mathrm{L}_{17}$ Technology / innovation exchange & $\checkmark$ & $\checkmark$ & & & \\
\hline $\mathrm{L}_{18}$ Trust & & & & & $\checkmark$ \\
\hline $\mathrm{L}_{19}$ Value of resource access & & & $\checkmark$ & & \\
\hline $\mathrm{L}_{20}$ Voluntary & & & & & \\
\hline
\end{tabular}


Table 2: Characteristics of Supplier-Manufacturer Relationships (answers from 34 managers to a direct question).

\begin{tabular}{|c|c|c|}
\hline Characteristic & $\begin{array}{c}\text { Example Quotes } \\
\end{array}$ & Mentions \\
\hline 1. Good & $\begin{array}{l}\text { "If you asked me directly, I can tell you that the relation- } \\
\text { ships with our suppliers are very good" (Purchasing Man- } \\
\text { ager in Engineering). }\end{array}$ & 14 \\
\hline 2. Partnership-like & $\begin{array}{l}\text { "Our relationships are partnership-like, which sums it up } \\
\text { pretty mисh" (Purchasing Manager in Process). }\end{array}$ & 9 \\
\hline 3. Co-operative & $\begin{array}{l}\text { "We are co-operative and this in objective terms. So, } \\
\text { working together does not only mean speaking about } \\
\text { things - joint actions are needed... It is a co-operative } \\
\text { effort and meetings are scheduled on a regular basis" } \\
\text { (Purchasing Manager in Engineering). }\end{array}$ & 5 \\
\hline $\begin{array}{l}\text { 4. Normal / Reason- } \\
\text { able }\end{array}$ & $\begin{array}{l}\text { "Our relationships are normal and based on what any } \\
\text { purchasing manager would reasonably expect" (Purchas- } \\
\text { ing Manager in Electronics). }\end{array}$ & 4 \\
\hline 5. Open & $\begin{array}{l}\text { "In my experience, our relationships are open which al- } \\
\text { lows us to address issues in an uncomplicated fashion" } \\
\text { (Managing Director in Engineering). }\end{array}$ & 3 \\
\hline $\begin{array}{l}\text { 6. Understanding / } \\
\text { Helpful }\end{array}$ & $\begin{array}{l}\text { "The supplier has to understand our problems and has } \\
\text { also to be helpful in solving these. I have the feeling that } \\
\text { these are the suppliers anybody should look out for" } \\
\text { (Managing Director in Electronics). }\end{array}$ & 3 \\
\hline $\begin{array}{l}\text { 7. Goal Directed / } \\
\text { Profit focus }\end{array}$ & $\begin{array}{l}\text { "The bottom-line is the goal in our business and so, the } \\
\text { supplier relationship has to measure up against profit." } \\
\text { (Purchasing Manager in Electronics). }\end{array}$ & 4 \\
\hline $\begin{array}{l}\text { 8. Human Factor is } \\
\text { important / Cli- } \\
\text { mate of trust }\end{array}$ & $\begin{array}{l}\text { "We developed our relationships in a way that we were } \\
\text { able to establish a climate of trust. The 'human factor' is } \\
\text { very important to us." (Purchasing Manager in Engineer- } \\
\text { ing). }\end{array}$ & 2 \\
\hline 9. Close & $\begin{array}{l}\text { "Our relationships are... close... in my view, being close } \\
\text { means that different functions should work together on } \\
\text { several level." (Managing Director in Engineering). }\end{array}$ & 1 \\
\hline 10. Direct & $\begin{array}{l}\text { "Our relationship is not so much on an organisational } \\
\text { level, but even more so, on a one-to-one basis. Hence, the } \\
\text { contact is very direct" (Managing Director in Process). }\end{array}$ & 1 \\
\hline 11. Liberal & $\begin{array}{l}\text { "We are highly liberal. Yes, we want to earn money, but I } \\
\text { don't have any advantage if an excellent supplier cannot } \\
\text { deliver components in two years time. Based on our under- } \\
\text { standing, there is always a way around problems" (Man- } \\
\text { aging Director in Engineering). }\end{array}$ & 1 \\
\hline $\begin{array}{l}\text { 12. Long-term per- } \\
\text { spective }\end{array}$ & $\begin{array}{l}\text { "Our relationships are built for the long-term and are } \\
\text { therefore sealed with a long-term contract" (Managing } \\
\text { Director in Process). }\end{array}$ & 1 \\
\hline $\begin{array}{l}\text { 13. Fair / "Giving and } \\
\text { Taking" }\end{array}$ & $\begin{array}{l}\text { "In general, the relationship has something to do with } \\
\text { 'giving and taking.' For instance, sometimes we forget to } \\
\text { order parts on time and the supplier sends an unscheduled } \\
\text { lorry on his expenses. At another time, I will order parts } \\
\text { from my preferred supplier although another source could } \\
\text { be considered. This is just fair and this situation I would } \\
\text { describe as 'giving and taking'” (Purchasing Manager in } \\
\text { Electronics). }\end{array}$ & 1 \\
\hline & Total & 49 \\
\hline
\end{tabular}


Table 3: Sample for Repertory Grid Interviews.

\begin{tabular}{|l|c|c|c|}
\hline Interviewees' Function & Engineering & Electronics & Total \\
\hline Purchasing Manager & 10 & 4 & 14 \\
\hline Managing Director & 4 & 6 & 6 \\
\hline Production Manager & 5 & 1 & 6 \\
\hline Quality Manager & 3 & 3 & 2 \\
\hline Logistics Manager & 1 & 1 & 1 \\
\hline R\&D / Purchasing Manager & & 1 & Total 39 \\
\hline
\end{tabular}


Table 4: How Constructs were Collated and Labels Assigned.

\begin{tabular}{|c|c|c|c|c|}
\hline $\begin{array}{c}\text { Construct } \\
\mathrm{No}^{2} . \\
\end{array}$ & $\begin{array}{c}\text { Construct } \\
\text { Label } \\
\end{array}$ & Poles & Example Respondents' Explanations & $\begin{array}{c}\text { Fre- } \\
\text { quency }\end{array}$ \\
\hline $\mathrm{E}_{1}$ & Flexibility & $\begin{array}{c}\text { Flexible (1); } \\
\text { Inflexible } \\
(5)\end{array}$ & $\begin{array}{l}\text { "A flexible supplier is prepared to work on weekends to fulfil } \\
\text { a short-termed order of us. The supplier is able to quickly } \\
\text { produce and deliver the parts. Other suppliers, inflexible ones, } \\
\text { are unable to fulfil these wishes" (Electronics; MD). } \\
\text { "If we order something under a very short notice - let's say } \\
\text { on a Friday - the supplier is so flexible that he even would } \\
\text { work on Saturdays and Sundays to deliver the parts on the } \\
\text { next business day; so on Monday. The same applies when or- } \\
\text { dering a small batch of parts. A flexible supplier can deliver } \\
\text { various volume sizes and not only the large ones. An inflexible } \\
\text { supplier cannot deliver parts to any other time or in any other } \\
\text { volume than what has been agreed in the contract long ago" } \\
\text { (Engineering; Purchasing Manager). }\end{array}$ & 23 \\
\hline $\mathrm{E}_{21}$ & $\begin{array}{l}\text { Joint } \\
\text { Problem } \\
\text { Solving }\end{array}$ & $\begin{array}{l}\text { Jointly (1); } \\
\text { Alone (5) }\end{array}$ & $\begin{array}{l}\text { "I can call a supplier if I have a problem and I can ask him } \\
\text { directly whether he can help me. Some help me to jointly solve } \\
\text { a problem, others don't help us at all" (Electronics; MD). } \\
\text { "Some suppliers help us solving our problems. I really get } \\
\text { full support in finding an answer to our problem. I can ring } \\
\text { them at any time and I would be certain that we will find a } \\
\text { way to overcome the problem together. I would also ring an- } \\
\text { other supplier, but others have obvious difficulties to see our } \\
\text { problems from our perspective and therefore, are unable to } \\
\text { solve it together with us. I even have to explain to them that I } \\
\text { need help in solving the problem; they simply don't seem to } \\
\text { understand what I mean by it. We always try to explain our } \\
\text { position to them, but - for reasons I am not aware of - they } \\
\text { seem to be unable to see the problem and the urgency to solve } \\
\text { it. They don't do it" (Electronics; Purchasing Manager). }\end{array}$ & 6 \\
\hline
\end{tabular}

\footnotetext{
${ }^{2}$ Construct reference numbers.
} 
Table 5: Empirical evidence of the attributes of partnership. Factors mentioned by $25 \%$ or more of respondents and a variability number greater than average are highlighted.

\begin{tabular}{|c|c|c|c|c|}
\hline No. & Constructs & \begin{tabular}{|c|} 
Frequency \\
(per cent of respon- \\
dents)
\end{tabular} & $\begin{array}{c}\text { Average Normalized } \\
\text { Variability } \\
\text { (per cent) }\end{array}$ & $\begin{array}{l}\text { Key Con- } \\
\text { struct? }\end{array}$ \\
\hline $\mathrm{E}_{1}$ & Flexibility & $23(59 \%)$ & 8.21 & No \\
\hline $\mathrm{E}_{2}$ & Delivery Performance & $20(51 \%)$ & 6.83 & No \\
\hline$E_{3}$ & Personal Relationship & $18(46 \%)$ & 11.15 & Yes \\
\hline $\mathrm{E}_{4}$ & Special Product Capability & $17(44 \%)$ & 12.76 & Yes \\
\hline $\mathrm{E}_{5}$ & Quality & $16(41 \%)$ & 6.76 & No \\
\hline $\mathrm{E}_{6}$ & Dependency & $15(38 \%)$ & 10.55 & Yes \\
\hline $\mathrm{E}_{7}$ & Size of Organization & $14(36 \%)$ & 11.42 & Yes \\
\hline $\mathrm{E}_{8}$ & Relationship Maintenance & $13(33 \%)$ & 10.08 & Yes \\
\hline $\mathrm{E}_{9}$ & $\begin{array}{l}\text { Volume of Turnover as bought from } \\
\text { the supplier }\end{array}$ & $13(33 \%)$ & 12.45 & Yes \\
\hline $\mathrm{E}_{10}$ & Price Level & $11(28 \%)$ & 4.93 & No \\
\hline$E_{11}$ & Feedback & $11(28 \%)$ & 10.21 & Yes \\
\hline$E_{12}$ & New Product Development & $10(26 \%)$ & 11.50 & Yes \\
\hline $\mathrm{E}_{13}$ & Complaint Handling & $10(26 \%)$ & 9.58 & Yes \\
\hline $\mathrm{E}_{14}$ & Location & $10(26 \%)$ & 9.48 & No \\
\hline $\mathrm{E}_{15}$ & Customer Oriented & $8(21 \%)$ & 7.64 & No \\
\hline $\mathrm{E}_{16}$ & Importance of Supplier (to Mfr) & $8(21 \%)$ & 10.24 & No \\
\hline$E_{17}$ & Openness & $7(18 \%)$ & 6.38 & No \\
\hline $\mathrm{E}_{18}$ & Price Changes & $7(18 \%)$ & 6.35 & No \\
\hline$E_{19}$ & Commitment & $6(15 \%)$ & 11.00 & No \\
\hline$E_{20}$ & Reliability & $6(15 \%)$ & 7.81 & No \\
\hline$E_{21}$ & Joint Problem Solving & $6(15 \%)$ & 7.58 & No \\
\hline $\mathrm{E}_{22}$ & Competence & $6(15 \%)$ & 6.97 & No \\
\hline$E_{23}$ & Organisational Culture & $5(13 \%)$ & 9.58 & No \\
\hline$E_{24}$ & Classification as a Customer & $5(13 \%)$ & 9.52 & No \\
\hline $\mathrm{E}_{25}$ & Duration of Relationship & $5(13 \%)$ & 10.47 & No \\
\hline$E_{26}$ & Designated Contact & $5(13 \%)$ & 8.90 & No \\
\hline
\end{tabular}


Figure I: Types of Relationships Source: Lambert et al. (1996, p2).

Partnerships

Arm's

\begin{tabular}{|c|c|c|c|}
\hline Type 1 & Type 2 & Type 3 & $\begin{array}{c}\text { Joint } \\
\text { Ventures }\end{array}$ \\
\hline
\end{tabular}

Vertical

Integration 
Figure II: $\quad$ Example Repertory Grid (Respondent 16-2: A Manager in the Electronics Sector).

\begin{tabular}{|c|c|c|c|c|c|c|c|c|c|c|c|}
\hline & \multirow[b]{2}{*}{ Constructs } & \multicolumn{9}{|c|}{ ELEMENTS - SUPPLIERS } & \multirow[b]{2}{*}{ Poles } \\
\hline & & $\begin{array}{c}\text { CARD } \\
1 \\
\text { Close }\end{array}$ & $\begin{array}{l}\text { CARD } \\
2 \\
\text { Distant }\end{array}$ & $\begin{array}{c}\text { CARD } \\
3 \\
\text { Distant }\end{array}$ & $\begin{array}{c}\text { CARD } \\
4 \\
\text { Average }\end{array}$ & $\begin{array}{c}\text { CARD } \\
5 \\
\text { Close }\end{array}$ & $\begin{array}{c}\text { CARD } \\
6 \\
\text { Average }\end{array}$ & $\begin{array}{l}\text { CARD } \\
7 \\
\text { Distant }\end{array}$ & $\begin{array}{c}\text { CARD } \\
8 \\
\text { Close }\end{array}$ & $\begin{array}{c}\text { CARD } \\
9 \\
\text { Average }\end{array}$ & \\
\hline 1 & Delivery Reliability on-time & $* 1 *$ & $* 4 *$ & $* 4 *$ & 3 & 2 & 3 & 4 & 2 & 3 & Delayed \\
\hline 2 & Product Quality High & 1 & 3 & 3 & $* 3 *$ & $* 2 *$ & $* 2 *$ & 3 & 1 & 3 & Low \\
\hline 3 & Price Level Low & 1 & 3 & 3 & 4 & 2 & 2 & $* 3 *$ & $* 2 *$ & $* 2 *$ & High \\
\hline 4 & Competence High & $* 1 *$ & 4 & 3 & $* 2 *$ & 1 & 2 & $* 3 *$ & 1 & 2 & Low \\
\hline 5 & Contact(s) always the same & 1 & $* 4 *$ & 3 & 2 & $* 1 *$ & 3 & 3 & $* 1 *$ & 2 & $\begin{array}{c}\text { Constantly } \\
\text { changing }\end{array}$ \\
\hline 6 & Makes decisions & 1 & 3 & $* 3 *$ & 3 & 1 & $* 3 *$ & 3 & 2 & $* 5 *$ & $\begin{array}{l}\text { Does not } \\
\text { decide any- } \\
\text { thing }\end{array}$ \\
\hline 7 & Early information & 1 & $* 3 *$ & 3 & $* 5 *$ & 1 & $* 3 *$ & 2 & 3 & 4 & $\begin{array}{l}\text { No informa- } \\
\text { tion }\end{array}$ \\
\hline 8 & Confident & 2 & 3 & $* 3 *$ & 2 & $* 1 *$ & 2 & $* 3 *$ & 3 & 1 & Clumsily \\
\hline 9 & Takes us seriously & 1 & 4 & 3 & $* 4 *$ & 2 & $* 2 *$ & 2 & $* 2 *$ & 3 & Arrogant \\
\hline 10 & Flexible & 1 & 3 & 3 & 4 & $* 1 *$ & 3 & $* 3 *$ & 3 & $* 3 *$ & Inflexible \\
\hline
\end{tabular}


Figure III: Venn Diagramm of the Attributes of Supplier Relationships.

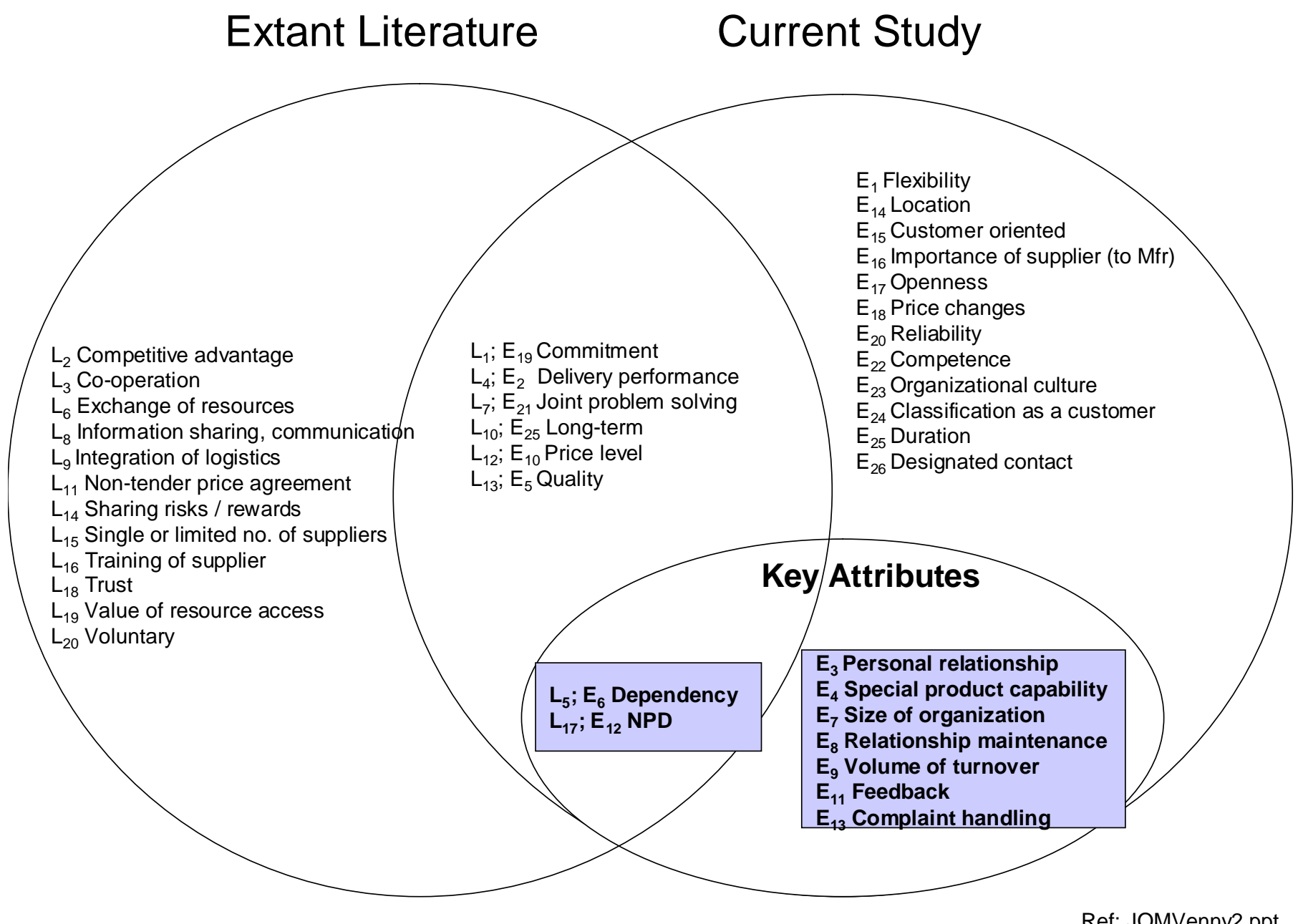


Figure IV: Conceptual Model of Supplier Partnerships (Based on the Literature and the Empirical Study).

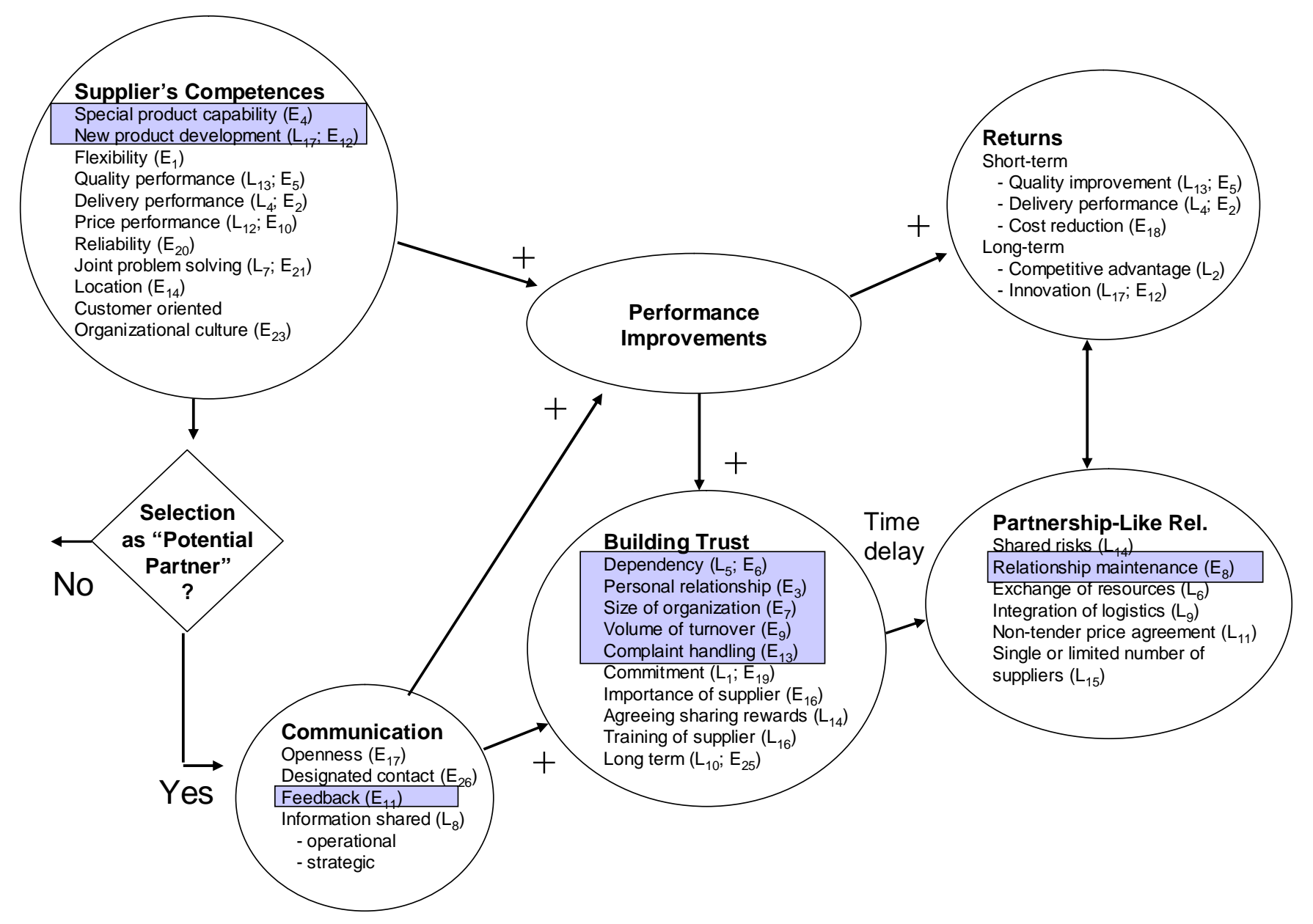

Ref: JOMModel2.ppt 